\section{Cloning's not a new idea: the Greeks had a word for it centuries ago}

Sir - The term 'cloning' originates from the Greek word clonos, meaning 'twig'; clonizo is the verb 'to cut twigs'. A kind of cloning has been widely used in agriculture for centuries: by this process a new tree is created from an adult tree's twig without use of its seed, analogous to the cloning of mammals from adult cells.

The idea that cloning is also possible in humans also evolved in ancient times: it was realized that the principles of reproduction did not lie in the reproductive organs or seed.

Joannes Philoponus, an Alexandrian philosopher of the sixth century AD, commenting on Aristotle's writings, observed: "If someone cuts a twig from a walnut tree in Athens and plants it in Patras [200 km away], two or three years later it will bear nuts that are the same in every aspect, in size and taste and colour and every other character, with the ones from the walnut tree in Athens.... So, if the resemblances between the plants do not originate because the seed comes from the entire body, as it was proved, but for some other reason, which [reason] he reveals later, the same applies to animals as well."

Philoponus used the word clados for 'twig', which is synonymous with clonos.

He was trying to find a reason for the resemblance between parents and children. Although he made many mistakes, he did correctly imagine the existence of some minimal part of the animal's body that contains all the information for the creation of the animal.

His thoughts were inspired by Aristotle. In his book On Animal Generation Aristotle proved that the information for the creation of an animal existed in all parts of the body but that, in opposition to other thinkers' beliefs, the semen did not come from the entire body in order to contain this information.

"Children are like their more remote ancestors from whom nothing has come," Aristotle wrote, "for the resemblances recur at an interval of many generations, as in the case of the woman in Elis who had intercourse with an Ethiop; her daughter was not an Ethiop but the son of that daughter was. The same thing applies also to plants."

Aristotle, many centuries before Mendel, referred to the properties of the propagation of genetic information in plants and humans. The fact that "resemblances recur at an interval of many generations" is probably Aristotle's most important observation in this regard, implying that certain characteristics do not have to be expressed to the next generation to be perpetuated.

"If again something creates this composition later," Aristotle continued, "it would be this that would be the cause of the resemblance, not the coming of the semen from every part of the body."

Today, we know that Aristotle's "something" is DNA. Aristotle understood that something undifferentiated exists that has the potential to become a plant or an animal, and that the semen is just the carrier of that potential.

Philoponus probably used a walnut tree rather than, say, an olive tree, intentionally. The word karyo (nut) also meant 'testicle', then as now, and is still used today in words such as karyotype and karyokinesis.

Using Aristotle's ideas about the transmission of information from parent to child, Philoponus suggested that a kind of cloning is possible in animals. Although the use of the term 'clone' by Philoponus is a very primitive example, it is the first reported use of the word for such a process.

One would not expect a thinker from the sixth century AD to be able to clone sheep, but, as with many other modern achievements, the principle was cultivated in the minds of the ancients.

A. A. Diamandopoulos, P. C. Goudas Chorio Romanou, 26500 Patras, Greece

\section{Taiwan pays the price for growth, in toxic pollution}

Sir - The environmental damage induced by the growth of Taiwan's technological revolution was not covered in your recent Insight feature about this country ${ }^{1}$. A century ago, British naturalist Alfred Russel Wallace was impressed with Taiwan's natural beauty ${ }^{2}$. But in the past few decades, this tiny island has evolved from agricultural backwater to global technological giant, leading to environmental disasters such as dangerously polluted rivers ${ }^{3,4}$.

In 1997, the government admitted that industry had produced 146,000 tons of hazardous waste ${ }^{3}$. Using recent data from 1,000 large industrial companies, the Environmental Protection Administration estimates that Taiwan produces more than 18 million tons of technological solid waste annually; 1.47 million tons of these are considered hazardous. Only 600,000 tons are treated - the rest ends up in rivers and landfills. About 50,000 tons of toxic solvents are produced annually, 35,000 tons by firms in Hsinchu, Taiwan's hightech industrial centre, alone ${ }^{1}$.

In July, 100 tons of toxic solvents were dumped into the country's second longest river, Kaoping, leaving 3 million residents (including us!) in and around Kaohsiung without drinking water for five days. In Taiwan's largest environmental criminal case to date, prosecutors alleged that the waste handler in the Kaoping affair dumped 14,000 tons of toxic solvents into river systems across the island. The government has discovered 160 illegal dump sites nationwide, of which the three most dangerous are near the river Kaoping. Furthermore, 100,000 barrels of toxic waste were recently discovered in central Taiwan, polluting the river Tatu. These examples of corporate greed are also the consequences of technological development.

Although mercury cell electrolysis was eliminated from the production line in 1989, Taiwan has accumulated mercury waste of about 100,000 tons, as estimated by the Industrial Development Bureau; an illegal mercury-tainted dump has recently been found in Hsinfeng town near Hsinchu. Taiwan currently has just one secure landfill, in Kaohsiung. It cannot handle all the toxic waste it produces, hence the government is seeking cashstarved countries that will dispose of it for a hefty fee. In a high-profile case last year, Cambodia returned 2,700 tons of Taiwan's mercury-laced waste after several deaths near the disposal site.

During the financial year 1999, Taiwan spent a large sum on national defence (20.5\% of the national budget), science and education (15.8\%), and economic development (13.5\%), but environmental protection remained a low priority $(1.5 \%)^{5}$.

Taiwan's technological miracle has taken place at the cost to our society of excessive toxic waste and pollution. The country now needs a profound reorientation in its attitude to the environment, with the help of the country's small but growing green movement. AD Govindasamy Agoramoorthy*,

\section{Minna J. Hsu $\dagger$}

${ }^{*}$ Department of Wildlife Conservation, National Pingtung University of Science \& Technology, Pingtung, Taiwan

†Department of Biological Sciences, National Sun Yat-sen University, Kaohsiung, Taiwan

1. Swinbanks, D. \& Cyranoski, D. Nature 407, 415-426 (2000).

2. Wallace, A. R. Island Life (Macmillan, London, 1880).

3. 1999 Republic of China Year Book (Government Information Office, Taipei, 1999).

4. Hsu, M. J. \& Agoramoorthy, G. Environ. Conserv. 25, 288-289 (1998).

5. Republic of China budget for 1999 in Chinese, www.dgbasey.gov.tw/account; the 1998 budget in English at http://www.dgbasey.gov.tw/english/dgbas_e3.htm.

Erratum The headline "Island-hopping invaders hitch a ride with tourists in South Georgia" (Nature 408, 637; 2000) should have read "in the Southern Ocean" instead of "in South Georgia". Nature apologizes for this error. 